\title{
TOURISM ADVISORY SERVICES IN THE CONTEXT OF NEW INSTITUTIONAL ECONOMICS
}

\author{
ANNA J. PARZONKO ${ }^{1}$ ANNA SIECZKO ${ }^{2}$ \\ Warsaw University of Life Sciences, POLAND \\ 1 e-mail: anna_parzonko@sggw.pl \\ 2 e-mail: anna_sieczko@sggw.pl \\ RECEIVED \\ ACCEPTED \\ JEL \\ CLASSIFICATION \\ KEYWORDS \\ ABSTRACT \\ 27 April 2017 \\ 16 November 2017 \\ D83, H83 \\ new institutional economics, tourism advisory services, agricultural advisory services, rural tourism, agritourism \\ New institutional economics focuses on the role of institutions, (such as advisory institutions), in economic de- \\ velopment and influencing human behaviour. The aim of this paper is to present the role played by agricultural \\ advisory institutions in stimulating development processes in rural areas. The study involves an analysis of the \\ operations of Mazowiecki Agricultural Advisory Centre in Warsaw underpinned by scientific literature review \\ which illustrate changes in the scope of advisory services provided in the field of rural tourism and the impact \\ this institution has had on entrepreneurial attitudes of rural residents. \\ Agricultural consultancies, through their operations, influence the change of attitudes of the rural population \\ - from the attitude involving merely 'waiting for grants' to entrepreneurial, cooperative attitudes, open to \\ innovations and tailored to market needs. The effectiveness of advisory services in Mazowieckie voivodeship \\ (Mazovia province) is proved by the increased number of agritourism farms regularly cooperating with advisors. \\ The most popular forms of delivered advice promoting agritourism included training provided in-house or as \\ a study visit and individual consultations.
}

\section{Introduction}

The theory of new institutional economics focuses on the role institutions play in economic development and influencing human behaviour. People's needs and the resulting human behaviour are greatly determined by both the social environment and institutional context. Therefore, an important role in the regulation of human behaviour is played by institutions which provide professional advice.

The aim of this paper is to present the role played by agricultural advisory institutions in stimulating development processes in rural areas in the field of tourism. The paper examines the operations of a selected advisory institution- 
Mazowiecki Agricultural Advisory Centre in Warsaw (MODR) - involving educational activities conducted in years 2005-2016 aimed to enhance the development of rural tourism in Mazovia region. The study involves the analysis of the operations of Mazowiecki Agricultural Advisory Centre in Warsaw underpinned by scientific literature review which illustrate changes in the scope of advisory services provided in the field of rural tourism and the impact this institution has had on entrepreneurial attitudes of rural residents.

\section{The Concept of New Institutional Economics}

The assumptions of the new institutional economics (NIE) seem appropriate to discuss the importance of agricultural advisory centres in the development of rural tourism and agritourism in Mazovia region in Poland. The term new institutional economics was coined by Oliver Williamson, who wanted to emphasize the difference between his new theory and old institutionalism (Stankiewicz, 2012). Other scholars who contributed to the theory include R. Coase, D.C. North, E. Williamson, E. Ostrom and G. Hodgson. The advocates of new institutional economics theory (Rosinska, 2008) argue that the world is changing, and the theory of economics should be changing too. Their approach, thus, builds on the achievements of neo-classical economics as well as on traditional institutionalism. In new institutional economics, economic analyses are supplemented by new approaches that let economic processes be explored from different angles. T. Legiędź (Legiędź, 2013) argues that the study of economic phenomena through econometric models has resulted in the simplification of socio-economic phenomena, which especially from the perspective of new institutional economics had a negative impact on the analysis itself. By narrowing the concept of institution to economic field, political domain or just a single institutional problem, researchers may present a fragmented and deformed picture of a problem, which in fact is much more complex. Therefore, the researchers working within NIE framework believe that problems in economics should be examined from interdisciplinary or trans-disciplinary perspective, which requires new methodological approach. New institutional economics assumes that the process of economic development is historically conditioned and the transformation of the institutional system is slow. In addition, it is influenced by the whole system of formal and informal institutions. As a consequence, the mere improvement of certain aspects of formal institutions does not necessarily have a positive impact on the entire institutional system, especially in the short run (Godłów-Legiędź, 2011). It is still unclear how institutions should be transformed to ensure economic growth. So far this issue has remained open.

Evaluation of an institution can be carried out from different perspectives (Brzozowski, Gierałtowski, Milczarek, Siwińska-Gorzelak, 2006):

- Does it fulfil the functions for which it was established?

- Does it distribute services/ attract customers effectively?

- Does it reduce uncertainty and support effective markets?

According to Miłaszewicz, good institutions create a structure of stimuli that reduce uncertainty and support effective markets for goods and factors of production, thus contributing to the improvement of economic performance (Miłaszewicz, 2011). For Wilkin, however, a good institution should be rooted in people's mind and influence their behaviour regularly and permanently (Wilkin, 2016). 


\section{Agricultural Advice in the Development of Rurpal Tourism}

Agricultural consultancies in Poland have supported rural development for over 100 years and have been integrated into the socio-cultural background of Polish agriculture for a long time. As an institution, agricultural advisory centres are well identified and trusted by farmers. The audit conducted by the Supreme Audit Office (NIK) showed that as many as $80 \%$ of farmers who have decided to use the advice of regional agricultural advisory centres are satisfied with the quality of provided services (NIK, 2014).

From the economic point of view, agricultural advice indirectly contributes to the transformation of certain microeconomic structures (agricultural holdings) and macroeconomic structures (agriculture, national economy) into efficient economic systems (King, 2013). According to Czyżewski and Matuszczak, future agriculture will follow dual path of development: some farms will adopt production methods that ensure high economic efficiency respecting only basic environmental requirements and minimizing undesirable social consequences, while other farms will go for more eco-friendly solutions (Czyżewski, Matuszak, 2009). The latter group of farmers follow the trend towards multifunctional agriculture, diversifying by adding non-agricultural business activities (including tourism) to traditional farming in the rural areas. Agricultural consultancies have played, a significant role in the development of rural tourism, including agritourism. Nowadays, the advisory services provided by agricultural advisory centres do not solely focus on agriculture. Agricultural advice now covers an extended scope of issues related to multifunctional rural development, including rural tourism. Tourism advice provided by agricultural advisory centres within the framework of agricultural advisory system involves assisting rural residents with various tourism initiatives such as: starting up and running agritourism farms, providing accommodation, organizing visitor transportation, developing tourist facilities, creating tourism products etc. The overarching objective of tourism advisory services is to equip people who run tourism businesses or have a plan to do so with sufficient know-how enabling them to take decisions and implement their projects independently (Parzonko, Sieczko, 2007).

The advisory services concerning tourism have evolved with time. Tourism advisory assistance focuses on the know-how of product offering to provide the visitors with knowledge, excitement, emotions and memorable experiences.

\section{Tourism Consultancy: Case of Mazowiecki Agricultural Advisory Centre}

Mazowieckie voivodeship (Mazovia province) in many respects is unique among Polish provinces. It is home to the city of Warsaw, which is the capital of Poland, the biggest Polish city and also a significant European metropolis. It is also the voivodeship with the biggest area (35.6 thousand square kilometres - nearly one eighth of Poland), the most populous (with a population over 5.2 million), with the highest GDP per capita, but also - the biggest development discrepancies in the country, with the capital city of Warsaw representing one end of the continuum and numerous areas outside the metropolis being at the other end (Strategy..., 2014). Even though Mazowieckie voivodeship is an area with low natural recreational value, (the natural conditions for recreation in the summer season are average and in the winter season - below average), in terms of the number of visitors' overnight stays it is comparable to voivodeships with more favourable natural conditions. 
Table 1. Number of overnight stays in total and in agritourism accommodation in Poland in 2015 by voivodeships

\begin{tabular}{lrc}
\hline \multicolumn{1}{c}{ Voivodeship (province) } & \multicolumn{1}{c}{ Total } & Agritourism farms \\
\hline Polska & $71,234,421$ & 452,071 \\
Dolnoślaskie & $6,829,669$ & 45,490 \\
Kujawsko-pomorskie & $3,625,536$ & 15,633 \\
Lubelskie & $1,711,623$ & 13,758 \\
Lubuskie & $1,289,145$ & 22,490 \\
Łódzkie & $2,302,010$ & 10,503 \\
Małopolskie & $10,942,837$ & 41,482 \\
Mazowieckie & $7,069,596$ & 22,556 \\
Opolskie & 730,094 & 9,634 \\
Podkarpackie & $2,772,613$ & 37,119 \\
Podlaskie & $1,128,140$ & 29,396 \\
Pomorskie & $7,880,472$ & 48,079 \\
Śląskie & $4,945,725$ & 25,650 \\
Świętokrzyskie & $1,466,752$ & 15,050 \\
Warmińsko-mazurskie & $2,831,860$ & 37,183 \\
Wielkopolskie & $3,378,292$ & 57,327 \\
Zachodniopomorskie & $12,330,057$ & 20,721 \\
\hline
\end{tabular}

Source: Turystyka w 2015 r.[Tourism in year 2015], Wydawnictwo GUS, Warszawa 2016, p. 215.

Rural tourism is a significant tourism trend in Mazowieckie voivodeship developing alongside other forms of tourism. It is part of multifunctional development of rural areas and allows for the diversification of income sources of the local population. The Mazowiecki Agricultural Advisory Centre with its registered office in Warsaw is one of the institutions which contribute to the economic development of rural areas in Mazovia through providing advice, education and information. In 1990s the Mazowiecki Agricultural Advisory Centre focused on looking for additional sources of income for rural residents in the Mazovia region and promoted agritourism and rural tourism. As a result in 2002 the advisors cooperated with 225 agritourism farms. The effectiveness of consultancy services in Mazowieckie voivodeship is evidenced by an increase in the number of agritourism farms regularly cooperating with advisors, which reached 347 in 2010. In 2016 The MODR in Warsaw provided services to 295 agritourism farms and other 25 rural tourism providers. Most of them are classic agricultural holdings which offer visitors hands-on experience of farm life, local culture, natural assets and healthy rural food.

The development of rural tourism reveals certain trends emerging from the changing visitors' needs. In addition to basic services like food and accommodation rural tourism providers develop packages of tourist services (network products in rural tourism) including leisure activities aimed to meet cognitive, emotional and social needs of the visitors. Agricultural advisors use a variety of methods, like trainings, demonstrations, exhibitions, fairs, competitions, regional food tastings, folk band concerts and artist shows, to encourage farm owners to diversify out of agriculture and support existing agritourism farms in expanding and enhancing their offer to meet the new trends in tourism. The MODR activity reports for the years 2005-2016 show that the most popular form of consultancy services delivered in the field of agritourism are in-house trainings and study visits. 
Table 2. Training courses on agritourism and their participants in 2005-2016 organized by the MODR in Warsaw

\begin{tabular}{|c|c|c|c|c|c|c|}
\hline & & 2005 & 2007 & 2010 & 2013 & 2016 \\
\hline \multirow{2}{*}{$\begin{array}{l}\text { In-house } \\
\text { trainings } \\
\text { and study visits }\end{array}$} & Number of courses & 59 & 56 & 56 & 42 & 42 \\
\hline & $\begin{array}{l}\text { Number of } \\
\text { participants }\end{array}$ & 930 & 883 & 801 & 611 & 919 \\
\hline
\end{tabular}

Source: Sprawozdania z realizacji programu działalności Mazowieckiego Ośrodka Doradztwa Rolniczego w Warszawie za lata 2005-2016. [Reports on the implementation of the program of Mazowiecki Agricultural Advisory Center in Warsaw for the years 2005-2016].

In 2005the training was mainly designed to address the needs of farmers planning to start an agritourism business, therefore mostly basic courses ending with the issuance of relevant certificates were provided. The farm and agritourism advisors cooperated with farmers preparing for a start-up. They provided advice, demonstrations and individual consultations delivered directly on the farm. Training materials such as 'Legal and Tax Aspects of Agritourism and Rural Tourism', 'Farm Holidays', 'Good Hygienic Practice (GHP) on Agritourism Farm' were developed and published. By contrast, as early as 2010, most of the training was focused on finding opportunities to expand the potential of the existing agritourism offer. The provided advice addressed such issues as categorization of venues, marketing and promotion, organization of various forms of active recreation and protection of the natural environment. In 2016, the provided training additionally focused on the need to create networking products and still promoted rural tourism as the additional source of income.

Each year the MODR staff provided advice concerning rural tourism. For example, in 2010 there were 4790 consultations, in 2013-4515 and in 2016-5331. The advisory programs most often focused on the quality of rural tourism and agritourism, the aesthetics of the farm and food served to tourists.

Additionally, the MODR in Warsaw also prepared:

1. Seven theme trails, which involved verification and analysis of the cultural and natural assets of Mazovia region;

2. Geocaching, a new tourist product, which is an outdoor recreational activity that involves seeking for hidden containers (caches) with the use of GPS devices.

The MODR is the only institution which for years has kept the register of agritourism farms and rural tourism facilities which they supervised and they published the catalogue 'Agritourism and Rural Tourism in Mazovia', which presents the offer of local rural tourism providers. In addition, the MODR is the organizer of competitions addressed to owners of agritourism farms, such as 'From Agritourism to Rural Tourism', which is recapped annually at a scientific conference 'Successes and Problems of Rural Tourism in Mazovia'.

Evaluation of the effectiveness of an institution, such as agricultural advisory centers, can focus on two dimensions: the assessment of an organization quality and customer satisfaction. The standard ISO 9001: 2008 is the most popular of all international standards for quality management also used to evaluate advisory organizations. Because the advisory centers are primarily acting for and in the interest of their clients, additional methods are needed to measure customer satisfaction. Such tools as a survey and focus interviews could give a deeper insight into the satisfaction of service recipients.

\section{Conclusions}

The operations of the Mazowiecki Agricultural Advisory Centre in Warsaw have served as an example to illustrate what role institutions can play in socio-economic development, in this case - the development of rural 
tourism. The advisory institutions, through their activities, stimulate the change of attitudes of the rural population - from the attitude involving merely waiting for grants to entrepreneurial, cooperative attitudes, open to innovations and tailored to market needs.

Being an institution which has actively supported rural development for years, the MODR in Warsaw has earned trust. This has been confirmed by the audit conducted by the Supreme Audit Office. It stimulates the development of rural tourism. As a result, there has been an increase in the number of organizations operating in rural tourism which cooperate with advisors by over $40 \%$ compared to 2002 .

Demand persists for training and advice regarding starting businesses in the field of rural tourism. Support for the existing rural tourism service providers should also include actions focusing on dissemination of information.

Advisory bodies, including MODR in Warsaw, try to evaluate the effectiveness of their activities. It motivates employees to work effectively as well as positively influences their perception by customers. There is a need for a unified evaluation standard for advisory institutions, taking into account both the technical and functional dimension.

\section{References}

Brzozowski, M., Gierałtowski, P., Milczarek, D., Siwińska-Gorzelak, J. (2006). Instytucje, polityka makroekonomiczna i wzrost gospodarczy. Warszawa: Uniwersytet Warszawski.

Czyżewski, B., Matuszczak, A. (2009). Powiązania instytucjonalne indywidualnych gospodarstw rolnych Polsce. Zagadnienia Ekonomiki Rolnej, 4 (62).

Godłów-Legiędź, J. (2011). Funkcje państwa i rynku z perspektywy kryzysu finansowego. Acta Universitatis Lodziensis Folia Oeconomica, 248 (15).

Agroturystyka w wydaniu MODR. Retrieved from: http://www.modr.mazowsze.pl/programy-i-projekty-ue/geocaching/1482agroturystyka-w-wydaniu-modr (7.04.2017).

Król, M.A. (2013). Model doradztwa rolniczego w Polsce na tle rozwiązań przyjętych wybranych krajach członkowskich Unii Europejskiej. Warszawa: FAPA.

Legiędź, T. (2013). Nowa ekonomia instytucjonalna a zmiany paradygmatu rozwoju gospodarczego. Ekonomia, 4 (25), 85-86.

Miłaszewicz, D. (2011). Jakość instytucji a wzrost gospodarczy. Zeszyty Naukowe Uniwersytetu Szczecińskiego. Studia i Prace Wydziału Nauk Ekonomicznych i Zarządzania, 19 (14).

0 ośrodkach doradztwa rolniczego. Retrieved from: https://www.nik.gov.pl/aktualnosci/rolnictwo/nik-o-osrodkach-doradztwarolniczego.html (7.04.2017).

Parzonko, A.J., Sieczko, A. 2007. Doradztwo turystyczne w Polsce. In: I. Sikorska-Wolak (ed.), Turystyka w rozwoju obszarów wiejskich (p. 392). Warszawa: Wydawnictwo SGGW.

Rosińska, M. (2008). Analiza ekonomiczna przedsiębiorstwa w oparciu o teorie instytucjonalne - koncepcja „instytucjonalizmu organizacyjnego przedsiębiorstw". Acta Universitatis Lodziensis Folia Oeconomica, 221, 257-275.

Sprawozdania z działalności Mazowieckiego Ośrodka Doradztwa Rolniczego w Warszawie za lata: 2005, 2006, 2007, 2008, 2009, 2010, 2011, 2012, 2013, 2014, 2015, 2016.

Stankiewicz, W. (2012). Ekonomika Instytucjonalna. Zarys wykładu. Warszawa: Wydawnictwo Prywatnej Wyższej Szkoły Businessu i Administracji.

Strategia rozwoju turystyki w województwie mazowieckim na lata 2014-2020. Retrieved from: www.mazovia.pl/../strategia_rozwoju_ turystyki_w_wojewodztwie_mazowieckim_na_lata_2014_-_2020.pdf (7.04.2017).

Wilkin, J. (2016). Instytucjonalne i kulturowe podstawy gospodarowania. Humanistyczna perspektywa ekonomii. Warszawa: Wydawnictwo Naukowe SCHOLAR.

Cite this article aS: Parzonko, A.J., Sieczko, A. (2017). Tourism advisory services in the context of New Institutional Economics. European Journal of Service Management, 4 (24), 23-50. DOI: 1.18276/ejsm.2017.24-07. 